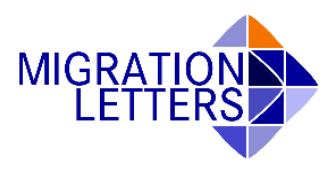

First Submitted: 25 October 2019 Accepted: 3 November 2019

DOI: https://doi.org/10.33182/ml.v17i1.853

\title{
The Repertoire of Extraterritorial Repression: Diasporas and Home States
}

\author{
A. Erdi Öztürk ${ }^{1}$ and Hakkı Taş
}

\begin{abstract}
This article scrutinises the extraterritorial repression strategies of contemporary non-democracies, as evidenced by the Turkish Justice and Development Party's efforts to purge the Gülen Movement globally after the 2016 coup attempt. Adopting "repertoire", as conceptualised by Charles Tilly, this article explores it in light of "extraterritorial repression," which includes the diverse skills and tactics mobilised to stifle dissent beyond national borders. This set of repressive measures is further directed at making claims on individuals and movements in the diaspora. By bringing attention to the repressive side of diaspora engagement, this article shows that diasporas are also shaped by repressive policies from their home countries.
\end{abstract}

Keywords: diasporas; migration; extraterritorial repression; authoritarianism; repertoire of resistance; repertoire of repression; Turkey.

\section{Introduction}

State power is increasingly extending its reach beyond national borders to affect diaspora communities. Whilst the Cold War strategy to restrict cross-border mobility, whether by erecting physical barriers or through fortification and enclosure, still holds, many authoritarian states are considering other options in light of the high cost and uncertain efficacy of maintaining control over their borders (Tsourapas, 2018). Developing diverse forms of transnational and extraterritorial authoritarianism, states have become more aggressive in their efforts to obstruct the political engagement of diaspora communities. For example, they pursue extraterritorial repression by utilising networks of informants abroad to conduct surveillance, hunt down dissidents, and hold relatives hostage (Cooley and Heathershaw, 2017; Glasius, 2018).

The 2018 murder of Saudi journalist Jamal Kashoggi in Turkey and the poisoning of Russian emigrants in the United Kingdom suggests a dangerous rise in the targeting of dissidents abroad by authoritarian regimes (Rutzen, 2015; Tansey, 2016). While this manner of extraterritorial repression is not unprecedented, it has largely remained a blind spot of scholarly research. On the one hand, diaspora studies overwhelmingly disregard the repressive practices of home states; the focus in this field being limited to how home states use their diasporas as resources for development and security or recruit them in service to nationalism (Gamlen 2014, 188). On the other hand, the study of authoritarianism, with more domestic and comparative approaches, overlooks how authoritarian states exert power beyond borders. This "extraterritorial gap" leaves the transnational space of

\footnotetext{
${ }^{1}$ Ahmet Erdi Öztürk, PhD, Lecturer, London Metropolitan University, London, United Kingdom.

E-mail: e.ozturk@londonmet.ac.uk.

${ }^{2}$ Hakkı Taş, PhD, Reseach Fellow at GIGA Hamburg, Germany.

E-mail: hakki.tas@giga-hamburg.de.
} 


\section{The Repertoire of Extraterritorial Repression}

authoritarian governance undertheorised (Dalmasso et al, 2018). A small, but emerging scholarship, is now focusing on repressive tactics devised by contemporary non-democracies to control their diasporas (Cooley \& Heathershaw, 2017; Michaelson, 2018), interventions that seek to control transnational space (Tsourapas, 2019), de-territorialised security practices (Moss, 2016; Adamson, 2018), the exportation of domestic conflicts abroad (Østergaard-Nielsen, 2003; Baser, 2015; Öztürk $\&$ Sözeri, 2018) and new means of diaspora engagement (Mencutek \& Baser, 2018).

By diverting attention to an alternative side of diaspora engagement, in this article, it is argued that home countries also engage in shaping their diasporas through repressive policies. The notion of "repertoire", as introduced by Charles Tilly, is adopted to capture the distinctive constellation of tactics employed collectively to make political claims $(1977,1995)$. While the "repertoire of contention" has informed much of the social movement literature (Snow et al., 2004), it is similarly useful for identifying the tactics of states making claims on individuals and movements in the diaspora. This article offers the term of "repertoire of extraterritorial repression" to encompass the diverse skills and tactics used by home states to stifle dissent beyond their borders. Repertoire enables a comprehensive approach to discern the robust mechanisms of extraterritorial repression, while also highlighting the dynamism that eventually paves the way to the invention, adaptation and transmission of such repressive measures.

As a case study, the global purge of the Gülen Movement (GM) ${ }^{3}$ by the ruling the Justice and Development Party (Adalet ve Kalkinma Partisi, AKP) since the 2016 abortive coup is scrutinised (Schenkkan, 2018). Beginning in the late 1980s, the Turkish state carried out diverse forms of extraterritorial repression aimed at several other "undesirable" socio-political groups, including Kurds, leftists, and some Islamist groups (Baser, 2013; Eccarius-Kelly, 2002). Likewise, Turkey's current repressive practices do not target the GM alone, but several opposition groups/figures as well, including Kurds, liberals, and signatories of the Academics for Peace declaration (Baser et al., 2017). Nevertheless, the specific example of the transnational GM underlines one of the most extensive and systematic cases of extraterritorial repression in the history of modern Turkey (Taş, 2019: 4-6; Watmough and Öztürk, 2018). This global purge, as a centralised, pre-planned state project, allows researchers to examine the intensification and multiplication of extraterritorial repressive practices and how such extraterritorial measures reconfigure diaspora-making.

The article begins with a brief overview of AKP-GM relations domestically and internationally. Then, the AKP's diaspora policy is sketched out and in particular, the new methods targeting GM members outside Turkey's borders are described. After providing a non-exclusive list of Turkey's repertoires of extraterritorial repression, the next section deals with the impacts of this extensive purge and the GM's transnational survival strategies. The article concludes with a brief observation linking the case to overall discussions on extraterritorial authoritarian practices. The article's analysis is based on insights derived from semi-structured interviews the authors conducted with GM members in the United Kingdom, Sweden, Germany, France, Bulgaria, North Macedonia, Albania and Greece between mid-2016 and mid-2019. Furthermore, a wide range of secondary sources, including official reports, statistics, and media coverage, is used to buttress the arguments laid out here.

\footnotetext{
${ }^{3}$ While the Gülen Movement has been labelled as the Fethullah Gülen Terror Organisation (FETÖ) by the Turkish state since mid-2105, the GM is referred to by its members as Hizmet (Service). These two opposite emic and etic depictions - Hizmet and FETÖ reflect the highly polarised and politicised context that also informs scholarly work on the subject. To maintain academic neutrality and critical distance, in this article, such value-laden tags are refrained from and instead, a neutral term, namely GM, is employed.
} 


\section{AKP-GM Relations at Home and Abroad}

At the beginning, the AKP represented hope for Turkey's democratisation (Insel, 2003). Even though there was some suspicion of its intents and democratic credentials (Haynes, 2010), it gained the support of both the mass public and the liberal socio-political intelligentsia in anticipation of the democratic gains in the European Union (EU) harmonisation process, particularly in the areas of human rights and civilian control of the military. What was framed as democratisation, however, required a bitter fight against the Kemalist establishment and its military-dominated tutelage system. In this power politics, the AKP and GM, despite their different religious lineages, established an unconventional, informal coalition against their common enemy (Öztürk, 2019: 89). Through this coalition, the AKP consolidated its electoral base and gained a strong ally, while GM members rose to powerful bureaucratic positions and expanded their activities abroad.

However, this strategic alliance was marked by hidden (2010-13) and overt (2013-16) periods of confrontation as a result of interest-based conflicts and fundamental disagreements on the Kurdish Question and bilateral relations with Iran and Israel (Taş, 2018a: 397-402). While the AKP tried to neutralise the influence of the GM within the state apparatus, the latter tried to discredit the former's legitimacy through its media and civil society organs. This conflict affected both the power struggle at home and Turkey's diaspora politics. By instrumentalising the threat of the GM, Erdoğan manipulated the party mechanism into a personal political apparatus. Similarly, the GM transformed itself into a socio-political organism that was more deliberately and aggressively fighting the power of a strong political leader. The growing crisis reached its peak during the 15 July 2016 bloody coup attempt, which was blamed on Gülen and his followers (Taş, 2018b: 5-7). In the aftermath of 15 July, Erdoğan changed the political system to an a la turca presidency and declared himself capable of spiriting away Turkey's "enemies" (Ceran, 2019: 180), including the GM. This carried the struggle beyond the borders of Turkey since most GM members had tried to avoid the national purge by traveling abroad. Erdoğan and Turkey's reach, however, superseded the national, leaving GM members in an extraterritorial purge.

\section{Turkey's Diaspora Engagement Under AKP Rule}

Even though Turkey has been a sending country since the late Ottoman period (Icduygu, 1996: 257), the emigration of Kurds (Sirkeci, 2006), Alevis (Sökefeld, 2003), and other opposition groups since the mid-twentieth century marked the emergence of new diaspora issues, such as transnationalisation, the importation of domestic conflicts (Feron, 2013; Baser, 2015), and the transfer of clandestine political resistance networks (Eccarius-Kelly, 2002). Moreover, the Turkish state's contentious relations with its oppositional diasporic communities have been the subject of various extraterritorial authoritarian measures, such as kidnapping and assassination (Adamson, 2013).

In 2002, the AKP came to power and began transforming Turkey's diaspora policy at the outset. First, it revived some of the existing transnational state apparatuses, such as the Presidency of Religious Affairs (Diyanet) (Öztürk, 2016). In addition, it established new institutions of diaspora engagement, such as the Yunus Emre Institutes and the Presidency of Turks Abroad and Related Communities, which were meant to serve diaspora members with a collaboration of civil society, the private sector, and the state (Baser, 2014). The new diaspora management, within the frames of public diplomacy and soft power, nurtured a kind of long-distance nationalism (Aydin, 2016) and Islamic culture. Whilst the multiplication of instruments and intensification of activities abroad have 


\section{The Repertoire of Extraterritorial Repression}

advanced Turkey's reach, they have also deepened the politicisation of Turkey's diaspora management. The majority of these policies are served and were conducted by pro-AKP groups, as well as their unconventional and informal coalition partners, including the GM. These soft power strategies, however, were outweighed by more repressive measures against the Gülenists after the public outburst of the AKP-GM conflict in late 2013. Albeit a predictable outcome, it is their collusion that not only strengthened AKP power, but also made the AKP fully aware of most of the Gülenist activities at home and abroad and eventually turned it to the most capable actor to pursue that kind of repression.

\section{Vertical and Horizontal Expansion}

Even though Turkey's extraterritorial authoritarian tendencies did not begin under AKP rule, it would seem fair to claim it has peaked in its transnational fight against the GM. After the 2016 abortive coup, theTurkish authorities initiated an extensive systematic global purge to suppress and root out all diasporic Gülenist formations (Schenkkan, 2018). In this all-out war, the state has multiplied its actors, hinting at the vertical expansion of extraterritorial repression, which include: a) the National Intelligence Organisation (Milli Istihbarat Teskilati, MIT); b) transnational state apparatuses, such as embassies, Diyanet and DITIB (Turkish-Islamic Union for Religious Affairs); c) government organised non-governmental organisations (GONGO) and think-tanks, such as the SETA Foundation for Political, Economic and Social Research (Siyaset Ekonomi ve Toplum Arastirmalari Vakfi); and, d) pro-AKP diaspora groups, associations, and members. In this regard, Turkish Intelligence has been carrying out different types of operations in accordance with a new law ${ }^{4}$ giving MIT the right to launch overseas operations against enemies of state. To this end, MIT is reported to have employed 800 operatives and 6,000 informants in Western Europe alone (Hamberger, 2016). Likewise, other transnational apparatuses, most notably Diyanet, have been conducting espionage outside their legal boundaries and collecting intelligence on Gülenists (Lical1, 2016). In addition to extending the role of Turkish Intelligence and other bureaucratic or stateaffiliated transnational institutions, the most important aspect of the AKP's diaspora management is its mobilisation and incorporation of non-state actors and recruiting their participation in advancing authoritarian policies. These vary from ordinary individuals spying on suspects in their neighbourhoods and mosques, to pro-government gangs intimidating Gülen followers. As Adamson argues, diasporic non-state groups may also employ illiberal practices featuring everyday forms of authoritarianism to pressurise for ideological conformity, thus discouraging opposition (2019).

This vertical expansion parallels a horizontal one in the repertoire of Turkey's extraterritorial repression. The activities included in this repertoire are a) abduction and extradition; b) confiscation; c) targeted violence; d) surveillance and profiling; e) negation and exclusion; f) negative propaganda; and, $\mathbf{g}$ ) the intimidation of relatives in the home country.

Abduction and extradition: The Turkish Police Department demanded that Interpol issue a "red notice" for sixty thousand Gülenists and other opponents abroad, but it refused (Yeni Şafak, 2017). The Turkish state then opted for overseas intelligence operations and exerted pressure on foreign countries to repatriate targeted Gülenists. In the three years following the 2016 coup attempt, Turkish pressure resulted in the extradition of 107 Gülenist suspects from countries, such as

\footnotetext{
${ }^{4}$ In 2014, with Law 2937, the State Intelligence Service (Devlet Istihbarat Hizmetleri) and the Turkish intelligence agency, MiT, were given the power to conduct overseas operations. For details on the law, see; http://www.mit.gov.tr/2937.html, last accessed 24 August 2019.
} 
Afghanistan, Angola, Bulgaria, Pakistan, and Sudan (Karadağ, 2019). The most notorious case among them is Kosovo, where six Turkish nationals with work and residence permits were arrested after an MIT operation in Pristina and delivered to Turkey via a private plane in March 2018 (Colborne and Edwards, 2018). While President Erdoğan's spokesperson Ibrahim Kalın argued that the event took place within the framework of an agreement on the return of criminals, the Kosovo parliamentary commission investigating this deportation found that it was in breach of national law and procedures. In the end, the Kosovo security chief and interior minister were dismissed from office (Ahval News, 2018). Similarly, the European Court of Human Rights found the arrest and extradition of five Gülenist schoolteachers from Moldova to Turkey as being an extra-legal transfer circumventing all guarantees offered by domestic and international law (ECHR, 2019). In the case of Malaysia, three men accused of ties to the GM were abducted through an intelligence operation in 2017. On 28 May 2019, the United Nations Human Rights Committee asked Turkey to release the suspects and compensate them for their arbitrary detention (2019).

Confiscation: With the GM known to hold a global education network spanning more than one thousand schools in nearly 160 countries, the AKP moved to co-opt or destroy the movement's transnational infrastructure. In 2016, the government instituted a new transnational apparatus, the Maarif Foundation, with a clear mission to take over educational institutions run by the GM. Turkey has confiscated and transferred nearly two hundred Gülenist schools to the Maarif Foundation, with official representation in 52 countries (Hürriyet Daily News, 2019).

Targeted Violence: Turkey's extraterritorial repression against the Gülenists has not reached acts of murder like the allegedly 2013 MIT-related killing of three Kurdish women activists in Paris. Nevertheless, state officials and pro-AKP groups have deliberately targeted diaspora Gülenists, leading to several lynchings and vandalisation of Gülenist institutions. These actions range from the attack on a cultural centre in Rotterdam to the beating of a Gülen-affiliate, Yavuz Koca, by Turkish consular officials in Essen, in 2017 (Ipanews, 2017). One should also add numerous cases of harassment, death threats, business blacklists, and calls to boycott Gülenist products and services (Carrel and Shalal, 2016). In this regard, the Turkish government also appears to have supported some gangs, including Osmanen Germania in Germany, which has been threatening opposition figures and groups (Spiegel Online, 2017). Such instances of lynching or threats send the message that there is no safe haven for Gülenists and as Ozan Ceyhun, a Turkish-born former German MEP wrote on social media: "Gülenists in Germany will have many sleepless nights" (De la Baume and Paravicini, 2016).

Surveillance and Profiling: In late 2016 and 2017, Diyanet and its imams in foreign countries appeared on the agenda of international policy makers and media due to its covert intelligence activities targeting suspected GM affiliates. A German investigation revealed Diyanet imams gathering intelligence and profiling their congregation across countries from continental Europe to Tajikistan and Kyrgyzstan (Hürriyet Daily News, 2017). Six Turkish imams, for instance, have been withdrawn from Germany owing to spying allegations (Kazim, 2017). Even though German prosecutors dropped the probe, the authorities in Belgium and the Netherlands announced they would take legal and political actions to curb Diyanet's intelligence activities (Deutsche Welle, 2017).

Beyond these espionage activities of transnational state apparatuses, Turkey has extended spying to ordinary pro-AKP diaspora members. For instance, Turkish Intelligence developed a smartphone application to be used to reveal GM members from among the Turkish diaspora in 


\section{The Repertoire of Extraterritorial Repression}

Germany to the authorities in Ankara. In 2019, the existence of this application was revealed in a report by the German Federal Office for the Protection of the Constitution (BfV). The same report alleged that some pro-AKP diaspora organisations were collecting intelligence in the service of MIT (Intelnews, 2019). More broadly, the digital surveillance of dissidents and activists through email intrusions, hacking, and regular monitoring of social media posts reinforces authoritarian information control beyond borders (Michaelson, 2018). While the scope and success of such practices are unknown, they imply the importation of domestic conflict in the form of extraterritorial repression.

Negation and Exclusion: As the most iconic example of exclusion, the Turkish government, in June 2017, officially threatened to strip 130 fugitives of their citizenship, if they did not return in three months (Hürriyet, 2017). More broadly, even after the 17-25 December 2013 corruption investigations in Turkey, Turkish foreign representative offices (embassies and consulates) as gatekeepers have denied GM affiliates fundamental services, whilst at the same time facilitating their return. After the coup attempt, the Turkish Foreign Ministry officially defined the GM as a terror organisation on its website and assumed an active role in the Gülenist purge. ${ }^{5}$ Likewise, other Turkish transnational state apparatuses and almost all non-GM Turkish diaspora organisations and associations have cut their services and any collaboration or cooperation with Gülenists due to the GM's new negative reputation.

Negative propaganda: In addition to the forceful measures employed by the AKP to intimidate Gülenist diasporans, it has also actively pursued a campaign securitising and defaming the GM. Institutional outposts, such as embassies and consulates, have promoted and defended AKP policies more forcefully since the 2016 abortive coup. While several pro-AKP civil society associations have taken a leading role in this negative propaganda and lobbying, some of their activities have been carried out in close cooperation with Turkish state authorities. Among these associations, the Foundation for Political, Economic and Social Research (Siyaset, Ekonomi ve Toplum Araştırmalart Vakfi, SETA) is the most prominent actor, with its large international organisational capacity and substantial number of research staff organising conferences in politically important metropoles, such as Brussels, London, and Washington DC, as well as publishing extensive reports on GM activities abroad (Bayraklı et al., 2018; İnat et al., 2018).

Intimidation of Relatives in the Home Country: Contemporary non-democracies aim at neutralising dissent abroad or pressuring activists to return home by threatening their significant others in the home country (Moss, 2016: 482). Turkey's post-coup purge largely relied on collective punishment and guilt by association (European Commission, 2016: 9), which also covered the detention of the relatives of Gülenists abroad. In the case of Enes Kanter, NBA player and a selfadmitted Gülenist, his family home in Istanbul was raided, his dentist imprisoned, as well as a man whose child took a photograph with Kanter (Whiteside, 2019).

\section{The Making and Re-Making of the Gülenist Diaspora}

After 15 July, the Turkish state carried out a massive crackdown of the GM, detaining at least 160,000 people, of which over 77,000 were formally arrested for alleged terror links (Taş, 2018b). With even more fired from their jobs as well as thousands of affiliated schools and firms being seized by the state, Gülenists themselves admit that the movement has no future in Turkey

${ }^{5}$ For details, see the official web-site of the Turkish Foreign Ministry, http://www.mfa.gov.tr/feto.tr.mfa, last accessed 24 August 2019. 
(Ashdown, 2018). Given the dire circumstances in Turkey, Fethullah Gülen encouraged his followers to leave Turkey and unite under the umbrella of 'Hizmet Diaspora' (Kiz1lkoyun, 2016). Either through regular or irregular means, many Gülenists have fled at any cost, seeking asylum in Europe. According to Eurostat figures, the number of first-time asylum seekers from Turkey increased five-fold in the European Union, from 4,165 such applications in 2015 to 21,955 in 2018 - leading to a total of 42,530 applications since the 2016 coup attempt - with the of majority of applicants coming from the GM (Figure 1). The movement has established solidarity networks, such as the Berlin-based Refugee Support Action (Aktion für Flüchtlingshilfe), to help newcomers get settled and to find language courses and jobs.

Figure 1: Second author's own rendering, based on Eurostat data [http://bit.ly/2vK3gWI]

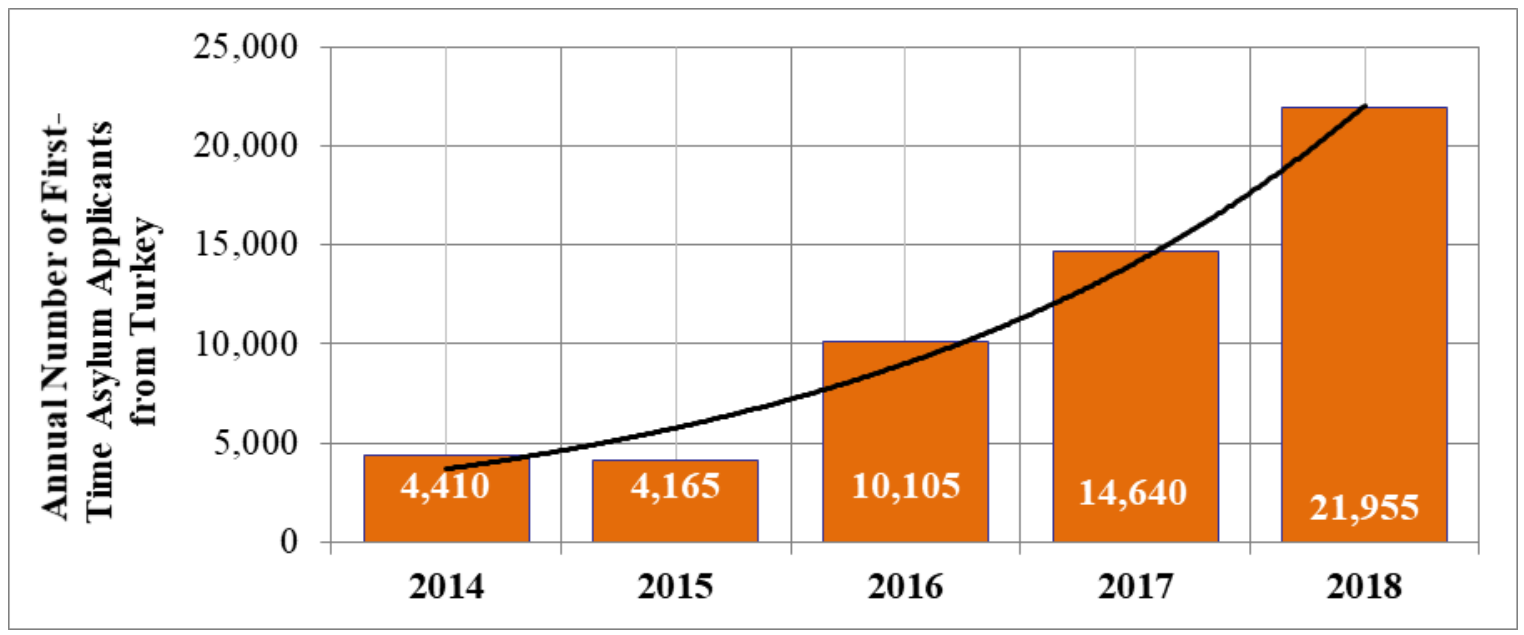

Nevertheless, as Moss points out, emigration does not necessarily entail liberation from authoritarianism (2016: 481). The AKP's extraterritorial repression has affected the GM's trajectory in several ways. The persecution at home and abroad, including the confiscation of hundreds of schools and nearly a thousand firm has cut off the GM's financial resources, which had been used to subsidise its overseas activities. With this diminished cash flow and new burden of helping its members in exile, the GM has ceased many of its transnational operations and downsized its institutional structure significantly (Sadar, 2018). With the AKP's active engagement with the Turkish diaspora and intense propaganda, the GM's base has shrunk significantly. In Germany, for instance, the estimated number of Gülen sympathizers dropped from 100,000- 150,000 to 60,00080,000 people, and several schools and tutoring centers were shut down (Süddeutsche Zeitung, 2017; Karakoyun, 2018: 36).

Moreover, given the GM had greater presence in the Global South, the vulnerability of these countries to the AKP's pressure impelled it to invest more in democratic European countries, with relative protection beyond the Turkish state's reach. Germany, with a total of 21,440 first-time applicants between August 2016 and December 2018 , is the top destination for Turkish asylumseekers (Figure 2), with many Gülenists now considering it to be their 'new hub' (Köhne and Siefert, 2018). According to the dataset provided by the United Nations Refugee Agency (2019), the main non-European host countries are again democratic, developed countries, such as the United States

\footnotetext{
${ }^{6}$ Regarding these sudden increases in asylum applications, see an earlier article in Migration Letters (Sirkeci, 2017: 137)
} 
(2,988 applicants), Canada (3,521 applicants), Japan (1,932 applicants) and Australia (448 applicants).

Figure 2: Second Author's own rendering, based on Eurostat data [http://bit.ly/2vK3gWI]

\begin{tabular}{|c|c|c|c|c|c|c|c|c|c|c|c|c|}
\hline \multirow{14}{*}{ 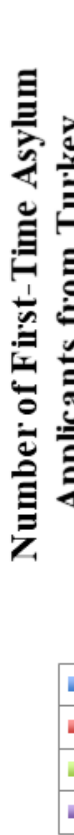 } & & 45,000 & & & & & & & & & & \\
\hline & & 40,000 & & & & & & & & & & \\
\hline & & 35,000 & & & & & & & & & & \\
\hline & & 30,000 & & & & & & & & & & \\
\hline & & 25,000 & & & & & & & & & & \\
\hline & & 20,000 & & & & & & & & & & \\
\hline & & 15,000 & & & & & & & & & & \\
\hline & & 10,000 & & & & & & & & & & \\
\hline & & 0 & & & & & & . & - I & & 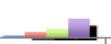 & \\
\hline & & & $\mathrm{EU}$ & Germany & Greece & France & $\begin{array}{c}\text { Netherla } \\
\text { nds }\end{array}$ & $\begin{array}{l}\text { Switzerl } \\
\text { and }\end{array}$ & Sweden & Belgium & UK & Norway \\
\hline & 20 & 5 (since Aug) & 5,935 & 3,250 & 130 & 460 & 195 & 245 & 540 & 530 & 255 & 65 \\
\hline & $=20$ & & 14,640 & 8,030 & 1,820 & 1,285 & 485 & 765 & 825 & 470 & 505 & 165 \\
\hline & 20 & & 21,955 & 10,160 & 4,820 & 2,045 & 1,310 & 915 & 430 & 780 & 780 & 765 \\
\hline & $=\mathrm{To}$ & & 42,530 & 21,440 & 6,770 & 3,790 & 1,990 & 1,925 & 1,795 & 1,780 & 1,540 & 995 \\
\hline
\end{tabular}

The AKP's active diaspora policy has had disparate effects on the Turkish diaspora and host countries. On the one hand, it has left the GM totally isolated from Turkish migrant communities, either because they share the AKP's view on the movement or fear being affiliated with it and the ensuing risk of repression. This isolation and polarisation exacerbate the intra-diaspora conflicts and limit the options for the GM. On the other hand, contrary to what the AKP hoped for, cases of extraterritorial repression strengthen the GM's victim status from the perspective of host countries, thus attributing greater legitimacy to its public presence (Taş, 2019). The GM has already benefited from the widespread anti-Erdoğan sentiment in the West. Moreover, the intimidation and pressure of Gülenist diasporans enable the GM to hide its earlier wrongdoings from the spotlight despite the abundance of criticism in circulation.

\section{Conclusion}

When politically-engaged opposition diasporas seek to bring political change to their homeland, states engage more and more with their diasporic communities to incorporate them into their domestic projects. With the transnationalisation of political activism, suppression of dissent at home is an insufficient solution for the survival or stability of non-democratic regimes. Such regimes are left to pursue repressive strategies towards oppositional groups within and beyond their borders. In the case of AKP-GM, the former waged a massive campaign, moving beyond traditional surveillance tactics by expanding extraterritorial repression, both vertically (multiplying the actors and institutions) and horizontally (intensifying and multiplying the instruments). 


\section{Özturk and Taş 67}

Repertoires are not static, but in constant formation. The AKP remodelled its already existing institutions (e.g. granting Turkish intelligence the right to carry out overseas operations) and invented new ones, such as the Maarif Foundation, to replace the GM in its educational network. However, the question of how home states employ diverse tactics in different host states on the basis of feasibility, legitimacy and effectiveness requires additional case studies and empirical verification. Likewise, theorisation to account for the recurring patterns and variations in repertoire constellations is viable only through broader comparative research that has yet to be undertaken. Just as transnational activists learn from each other, authoritarian states imitate each other, replicating or importing new tactics, and eventually leading to the diffusion of extraterritorial repressive policies. Additional research needs to be carried out exploring the mechanisms behind the transmission and adaptation of such tactical repertoires.

\section{References}

Adamson, F. (2013). Mechanisms of diaspora mobilization and the transnationalization of civil war. In J.T. Checkel (ed.)., Transnational dynamics of civil war (pp. 63-88). Cambridge: Cambridge University Press. https://doi.org/10.1017/CBO9781139179089.006

Adamson, F. (2019). Non-state authoritarianism and diaspora politics. Global Networks. https://doi.org/10.1111/glob.12246.

Ahval News. (2018). Kosovo PM sacks intelligence chief, interior minister after extradition of Turkish nationals. 30 March. Retrieved from https://ahvalnews.com/kosova/kosovo-pm-sacks-intelligence-chief-interior-minister-afterextradition-turkish-nationals.

Ashdown, N. (2018). Loathed, hunted down, Gülen Movement finished in Turkey. Ahval, 28 February. Retrieved from https://ahvalnews.com/turkey/loathed-hunted-down-gulen-movement-finished-turkey.

Aydin, Y. (2016). The German-Turkey Migration Corridor: Refitting Policies for a Transnational Age. Washington DC: Migration Policy Institute.

Baser, B. (2013). Diasporas and imported-conflicts: The case of Turkish and Kurdish second generation in Sweden. Journal of Conflict Transformation and Security, 3, 105-125.

Baser, B. (2014). The awakening of a latent diaspora: The political mobilization of first and second gneneration Turkish migrants in Sweden. Ethnopolitics, 13(4), 355-376. https://doi.org/10.1080/17449057.2014.894175

Baser, B. (2015). Diasporas and homeland conflicts: A comparative perspective. Farnham: Ashgate. https://doi.org/10.4324/9781315577012

Baser, B., Akgönül, S., \& Öztürk, A. E. (2017). "Academics for Peace" in Turkey: a case of criminalising dissent and critical thought via counterterrorism policy. Critical Studies on Terrorism, 10(2), 274-296. https://doi.org/10.1080/17539153.2017.1326559

Bayraklı, E., Boyraz H.M., and Güngörmez O. (2018). FETÖ'nin Birleşik Krallık Yapılanması. İstanbul: SETA.

Carrel, P., and Shalal, A. (2016) .Tensions Rise in Germany's Turkish Diaspora, Mirroring Splits in Turkey. Reuters, 2 September. Retrieved from https://www.reuters.com/article/uk-turkey-security-germany-insight/tensions-rise-ingermanys-turkish-diaspora-mirroring-splits-in-turkey-idUSKCN1181 WK.

Ceran, F. (2019). From paradigm shift to retooling: the foundation and maintenance of the AKP. Southeast European and Black Sea Studies, 19(1), 175-193. https://doi.org/10.1080/14683857.2019.1579858

Colborne, M., and Edwards, M. (2018). Erdogan's Long Arm: The Turkish Dissidents Kidnapped From Europe. Haaretz. 30 August.

Cooley, A., and Heathershaw, J. (2017). Dictators without borders: Power and money in Central Asia. New Haven: Yale University Press.

Dalmasso, E., Del Sordi, A., Glasius, M., Hirt, N.; Michaelsen, M., Abdulkader S., and Moss, D. (2018). Intervention: Extraterritorial authoritarian power. Political Geography 64, 95-104. https://doi.org/10.1016/j.polgeo.2017.07.003

De la Baume, M., and Paravicini, G. (2016). "Sleepless nights" for Gülen's supporters in Europe. Politico. 22 August. Retrieved from https://www.politico.eu/article/sleepless-nights-for-fetullah-gulen-supporters-in-europe-erdoganturkey-coup/.

Deutsche Welle. (2017). German Prosecutors Drop Probe into Suspected Turkish Imams Spies. 6 December. Retrieved from https://www.dw.com/en/german-prosecutors-drop-probe-into-suspected-turkish-imam-spies/a-41672175.

Eccarius-Kelly, V. (2002). Political movements and leverage points: Kurdish activism in the European diaspora. Journal of Muslim Minority Affairs, 22(1), 91-118. https://doi.org/10.1080/13602000220124854 


\section{The Repertoire of Extraterritorial Repression}

ECHR. (2019). Extradition of five school teachers to Turkey because of alleged ties with the Gülen movement was in breach of the Convention. Press Release ECHR 213, 11 June.

European Commission. (2016). Commission staff working document - Turkey 2016 Report. SWD/2016/0366. November 9.

Feron, E. (2013). Diaspora politics: from "long distance nationalism" to autonomization. In Halm, D. and Sezgin, Z. (eds.). Migration and Organized Civil Society - Rethinking National Policy (pp. 76-91). London: Routledge.

Gamlen, Al. (2014). Diaspora Institutions and Diaspora Governance. International Migration Review 48, S180-S217. https://doi.org/10.1111/imre.12136

Glasius, M. (2018). Extraterritorial authoritarian practices: a framework. Globalization, 15(2), 179-197. https://doi.org/10.1080/14747731.2017.1403781

Hamberger, K. (2016). Grünen-Politiker beantragt Einberufung des Kontrollgremiums. Deutschlandfunk. 22 August. Retrieved from https://www.deutschlandfunk.de/bericht-ueber-tuerkische-spitzel-gruenenpolitiker.1766.de.html?dram:article_id=363736.

Haynes, J. (2010). Politics, identity and religious nationalism in Turkey: from Atatürk to the AKP. Australian Journal of International Affairs, 64(3), 312-327. https://doi.org/10.1080/10357711003736477

Hürriyet Daily News. (2017). Directorate of Religious Affairs Recalls Imams Accused of Spying in Germany, 10 February. Retrieved from http://www.hurriyetdailynews.com/directorate-of-religious-affairs-recalls-imams-accusedof-spying-in-germany--109614.

Hürriyet Daily News. (2019). Turkey's Maarif teaches 30,000 students in 35 countries. 17 June. Retrieved from http://www.hurriyetdailynews.com/turkeys-maarif-teaches-30-000-students-in-35-countries-144260.

Hürriyet. (2017). Süre Doldu! İşte vatandaşlıktan çıkarılacak 130 isim. 6 September.

İçduygu, A. (1996). Becoming a new citizen in an immigration country: Turks in Australia and Sweden and some comparative implications. International Migration, 34(2), 257-272. https://doi.org/10.1111/j.14682435.1996.tb00525.x

İnat, K., Bayraklı, E., Keskin, K., Yılmaz, Ö., Doğan, H.İ, Can, S., and Eliaçık, Z. (2018). Almanya'da FETÖ Yapılanmas1 ve Almanya'nın FETÖ Politikası. İstanbul: SETA.

Insel, A. (2003). The AKP and normalizing democracy in Turkey. The South Atlantic Quarterly, 102(2), 293-308. https://doi.org/10.1215/00382876-102-2-3-293

Intelnews. (2019). Turkish Spy Agency Develops Phone App to Help Ex-pats Inform on Dissidents. 10 June. Retrieved from https://intelnews.org/2019/06/10/01-2565/?fbclid=IwAR3johRJqVxs5z2OVAeHkllMFuUxqsGiLSNPT jE9blukwNTtSd6Tz1U1jyo.

Ipanews. (2018). Turkey's own Kashoggi Moment. 31 December. Retrieved from https://ipa.news/2018/12/28/turkishconsulate-staff-in-germany-beats-threatens-school-principal/.

Karadağ, K. (2019). 107 FETo fugitives brought back to Turkey so far, AA. 27 March. Retrieved from www.aa.com.tr/en/turkey/107-feto-fugitives-brought-back-to-turkey-so-far/1431325.

Karakoyun, E. (2018). Egal wo ihr seid, wir finden euch! - Erdoğan (Bericht über die Verfolgung der Gülen-Bewegung). Berlin: Stiftung Dialog und Bildung.

Kazim, H. (2017). Global Spying Network: Turkey's Worldwide Monitoring of Suspected Gülen Supporters. Spiegel Online. 31 March. Retrieved from http://www.spiegel.de/international/europe/turkey-spies-on-suspected-guelensupporters-around-the-world-a-1141367.html.

Kızılkoyun, F. (2016). Gülen Orders Followers to "Unite" Abroad. Hürriyet Daily News. 15 August.

Köhne, G., and Siefert, V. (2018). die Gülen-Bewegung: Neues Zentrum "Almanya." Deutsche Welle. 13 July. Retrieved from www.dw.com/de/die-gülen-bewegung-neues- zentrum-almanya/a-44645120.

Lical1, M. (2016). Diyanet MíT gibi. Cumhuriyet. 8 December.

Mencutek, Z. S., and Baser, B. (2018). Mobilizing diasporas: Insights from Turkey's attempts to reach Turkish citizens abroad. Journal of Balkans and Near Eastern Studies, 20(1), 86-105. https://doi.org/10.1080/19448953.2017.1375269

Michaelsen, M. (2018). Exit and voice in a digital age: Iran's exiled activists and the authoritarian state. Globalizations, 15(2), 248-264. https://doi.org/10.1080/14747731.2016.1263078

Moss, D. M. (2016). Transnational repression, diaspora mobilization, and the case of the Arab Spring. Social Problems, 63(4), 480-498. https://doi.org/10.1093/socpro/spw019

Østergaard-Nielsen, E. (2003). The politics of migrants' transnational political practices. International migration review, 37(3), 760-786. https://doi.org/10.1111/j.1747-7379.2003.tb00157.x

Öztürk, A. E. (2016). Turkey's Diyanet under AKP rule: from protector to imposer of state ideology?. Southeast European and Black Sea Studies, 16(4), 619-635. https://doi.org/10.1080/14683857.2016.1233663 


\section{Özturk and Taş 69}

Öztürk, A. E. (2019). An alternative reading of religion and authoritarianism: the new logic between religion and state in the AKP's New Turkey. Southeast European and Black Sea Studies, 19(1), 79-98. https://doi.org/10.1080/14683857.2019.1576370

Öztürk, A. E., and Sözeri, S. (2018). Diyanet as a Turkish foreign policy tool: Evidence from the Netherlands and Bulgaria. Politics and Religion, 11(3), 624-648. https://doi.org/10.1017/S175504831700075X

Rutzen, D. (2015). Authoritarianism Goes Global (II): Civil Society Under Assault. Journal of Democracy, 26(4), 28-39. https://doi.org/10.1353/jod.2015.0071

Sadar, C. (2018). Gülenist Lobbyists in Washington Cash-Strapped, but Find Sympathetic Audience. Ahval. 31 July 31. Retrieved from https://ahvalnews.com/turkey/gulenist-lobbyists-washington-cash-strapped-find-sympatheticaudience.

Schenkkan, N. (2018). The Remarkable Scale of Turkey's "Global Purge." Foreign Affairs. 29 Janaury.

Sirkeci, I. (2006). The environment of insecurity in Turkey and the emigration of Turkish Kurds to Germany. New York and Lampeter: Edwin Mellen Press.

Sirkeci, I. (2017). Turkey's refugees, Syrians and refugees from Turkey: a country of insecurity. Migration Letters, 14(1), 127-144. https://doi.org/10.33182/ml.v14i1.321

Snow, D.A., Soule, S.A., and Kriesi, H. (eds.) (2004). The Blackwell Companion to Social Movements. MA: Blackwell. https://doi.org/10.1002/9780470999103

Sökefeld, M. (2003). Alevis in Germany and the Politics of Recognition. New Perspectives on Turkey, 29, 133-161. https://oi.org/10.1017/S0896634600006142

Spiegel Online. (2017). Erdogan-Vertrauter soll deutschtürkische Rocker mit Geld versorgt haben. 12 December. Retrieved from https://www.spiegel.de/politik/deutschland/osmanen-germania-erdogan-vertrauter-soll-rocker-mitgeld-versorgt-haben-a-1183006.html.

Süddeutsche Zeitung. (2017), Türkei: Mehr als 1000 Festnahmen. 31 July.

Tansey, O. (2016). International politics of authoritarian rule. Oxford: Oxford University Press. https://doi.org/10.1093/acprof:oso/9780199683628.001.0001

Taş, H. (2018a). A history of Turkey's AKP-Gülen conflict. Mediterranean Politics, 23(3), 395-402. https://doi.org/10.1080/13629395.2017.1328766

Taş, H. (2018b). The 15 July abortive coup and post-truth politics in Turkey. Southeast European and Black Sea Studies, 18(1), 1-19. https://doi.org/10.1080/14683857.2018.1452374

Taş, H. (2019). The Gülenists in Exile: Reviving the Movement as a Diaspora. GIGA Focus 3. Retrieved from https://www.giga-hamburg.de/en/system/files/publications/gf_nahost_1903_en.pdf.

Tilly, C. (1977). From Mobilization to Revolution. Reading, MA: Addison Wesley.

Tilly, C. (1995). Popular Contention in Great Britain, 1758-1834. Cambridge, MA: Harvard University Press.

Tsourapas, G. (2018). Authoritarian emigration states: Soft power and cross-border mobility in the Middle East. International Political Science Review, 39(3), 400-416. https://doi.org/10.1177/0192512118759902

Tsourapas, G. (2019). The Syrian refugee crisis and foreign policy decision-making in Jordan, Lebanon, and Turkey. Journal of Global Security Studies, 4(4): 464-481. https://doi.org/10.1093/jogss/ogz016

United Nations Human Rights Council. (2019). Views adopted by the Committee under the Optional Protocol, concerning communication No. 2980/2017. 28 May.

United Nations Refugee Agency. (2019). Data- Asylum Seekers Monthly. Retrieved from http://popstats.unhcr.org/en/asylum_seekers_monthly.

Watmough, S. P., \& Öztürk, A. E. (2018). From "diaspora by design" to transnational political exile: the Gülen Movement in transition. Politics, Religion \& Ideology, 19(1), 33-52. https://doi.org/10.1080/21567689.2018.1453254

Whiteside, K. (2019). An N.B.A Star takes on Erdogan. The New York Times. 9 January.

Yavuz, M. H. (2018). A framework for understanding the intra-Islamist conflict between the AK party and the Gülen movement. Politics, Religion \& Ideology, 19(1), 11-32. https://doi.org/10.1080/21567689.2018.1453247

Yeni Şafak. (2017). FETÖ takes advantage of Interpol decision. 5 July. Retrieved from https://www.yenisafak.com/en/news/feto-takes-advantage-of-interpols-decision-2748646. 
70 The Repertoire of Extraterritorial Repression 